\title{
事務所設計の個別要求条件整理の費用回収について A STUDY ON COST COLLECTION OF PRE-DESIGN RESEARCH FOR OFFICES
}

\author{
柳父行二* \\ Koji YANABU
}

\begin{abstract}
A model for calculating the break even points among facilities investments and benefits induced by facilities, was constructed and cost collection of pre-design research for offices was discussed. Applying the model reveals that the rate of building construction to the total expense for office tenants is smaller than that for building owners. Some calculations on break even points reveal that pre-design research with a focus on space saving of one square meter or time saving, especially one minute in every working day for as many workers as possible, is valuable and provides a chance to collect human expenditure for the purpose of research.
\end{abstract}

Key words: office planning, facilities management, cost performance, life cycle cost, オフィス計画、F M 、投資効果、L C C

\section{1.はじめに}

設計要求条件整理（Pre-Design Research一以下P D R）には一般的 な設計事例を参考とする方法と個別事情を反映させる方法がある。 前者の事例には、事務所のエレベーター設計で「 5 分間到着人数を 5 分間で搬送する」という考え方を適用し、5 分間到着人数は利用 が集中する出勤時の実測値に基づく目安が利用されている注1)のが 挙げられる。 5 分間到着人数は居住人口に対する比として表わさ れ、一棟借りのような始業時間が全員同じ場合と、テナントビルで 始業時間がバラバラの場合では異なる数值を適用している注1。一 棟借りでもフレックスタイム制や直行直帰制が実施されると出勤時 のピークが穏やかとなり、出勤時の混雑が緩和される可能性があ る。そのような事務所で出勤時の 5 分間到着人数を測定し、個別事 情を反映させることにより、エレベーターの定員や台数が削隇出 来、建設費並びに維持運用費が減額できる可能性がある。

個別事情を反映させて投資効果を向上させることが出来るなら、

「雑巾を絞る」という考えを建築にも適用することができる。但 し、個別事情を反映させるには、調査・分析 · 意思決定のための追 加費用が必要で、結果が一般解と同じであったり、P D R 費用が建 設費削減等による減額を上回る場合には、「雑巾を絞る」という目 論見は水泡に帰する。

そこで本論文では、「雑巾を絞る」ための費用と、建築費等の追 加削減額、並びに「杂倠巾を絞った」結果として得られる利益の関係
をモデル化し、個別解を求めるための許容費用について考察する。 但し効果を計量することは難しく、P D R 費と建築費の比率も様々 であるので、幾つかの仮定を導入し「目安」を考察する。

\section{2. 投資と効果のモデル化}

2-1 オーナーモデル

建築の生涯費用を計算したモデルに、建設省官庁営縓部の65年モ デルや建築・設備維持保全推進協会（BＥＬＣＡ）の40年モデルが ある注2)。建設費の割合はそれぞれ $15.9 \%$ と $25.3 \%$ 、㓍工後に必要 な運用・保全 ·修繥 ·更新 - 一般管理費が削減できるなら、初期投 資が増加しても総費用は削減できる場合があるとされる注3)（Life Cycle Cost - 以下 L C C)。

L C C の適用例には、部材の耐久性を高め維持管理費用を削減し た送電鉄塔注 4)、外壁や床の耐久性を高め維持管理費用を減少させ た住宅やビル注4)、システムの信頼性を向上させ維持管理費を減少 させた鉄道の無人改札システムや安全対策注4)、高い総合熱効率で 運用費を減少させたコジェネレーション注5)などがある。

L C C は総費用の削減だけではなく収入增につながる工夫も含ま れ、賃料増大ならびに入居率向上のためののための設備の充実等の 事例もある注6)。

建設省の65年モデルや B E L C A の40年モデルの積算項目注7) は、図 1 に示す費用の流れの中のビルオーナーの支出に相当する。 
従ってオーナーモデルと称することが出来る。

\section{$2-2$ テナントモデル}

オーナーモデルがオーナーの支出に注目したようにテナントの支 出に注目する。事務所テナントの業務遂行のための投資には、雇用 保険料・健康保険料 ·退職引当金を含む人件費、オーナーに支払う スペース賃料、事務の素材である情報の入手費、事務作業に必要な 鉛筆・消ゴム・帳票並びにパソコン・家具等の道具、良好な作業環 境を維持するために必要な光熱費等が挙げられる（図 1)。現実的 な数值注8) を用いて事務所建築費とテナントのオフィス経営費を計 算すると、テナント経営者は毎年建築費の約 2 割相当額をスペース 賃料としてオーナーに支払い、約 2 倍の費用を業務遂行に投資して いることが分かる（図 2 ）。

テナントモデルで建築費の占める割合は 65 年モデルで $0.7 \% 、 40$ 年 モデルで $1.2 \%$ に過ぎず注 9 、、オーナーモデルより「桁違いに」小さ い。従って、個別事情を反映させオフィス経営費に関わる部分で削 減が見込めるなら、その効果を捻出するための追加費用も短期間で 回収出来る可能性がある。

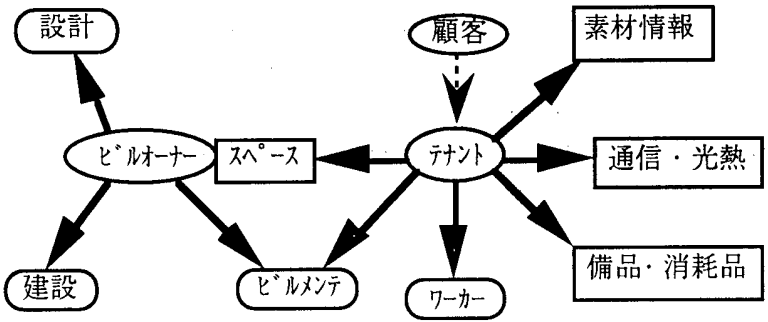

図 1 建築関連メンバーと費用の流れ
3.プロフィットセンターモデルによる損益分岐試算

3-1. プロフィットセンターモデル

テナント側でFacilitiesの充実に伴う投資効果を考える場合、投資 にはFacilitiesそのものの費用の他に、Facilities充実のための要求条件 の整理に要した人件費、導入教育費、運用費、そして廃棄費用が挙 げられる。効果にはFacilities充実に伴う業務成果の増大や商品の売 り上げで把握することが望まれる。しかし、業務成果が商品として 取引され成果の金額が確定するまでに販売活動他の要素が影響する と、Facilities整備に伴う影響を分離することが難しい。

そこで、Facilities整備に伴う効果として、販売額の代わりに業務 成果增大に貢献しうる業務時間とスペースの捻出に着目し、時間を 人件費に換算したもの並びにスペース賃料を効果の金額表示とする

(図 3)。この仮定により効果の精度が低下し「目安」の考察にな らざるを得ないが、Facilities整備に起因する業務成果の分離と金額 表示という「暗礁」で留まっていては成し得ない考察が可能になる と考えられる。

初期投資の増加を運用開始後の費用削減で回収する場合、効果は 全体費用の中で大きな割合を占める部分に求めるのが良い。テナン トモデルの場合は、オフィス経営費が最も多くスペース賃料が 2 番 目となる。両者に及ほすす効果は、組織や業務の仕組の変更で減損し たり、機能陳腐化に伴う Facilitiesの入れ替えで消滅する場合がある ため、何十年もの長い期間継続すると想定するのは現実的ではない と考えられる。

そこで、投資回収期間と効果の金額表示に以下の仮定を導入し、 損益分岐点を試算する。

まず投資回収期間は、導入検討費用と導入教育費用が 1 年、

Facilities購入費はリース期間とする。この仮定により、公租公課と 物価上昇の複雑な計算を回避し廃亲費用も考慮でき、2 年目以降と 1 次リース期間終了後に費用が削減できるモデルができる（図

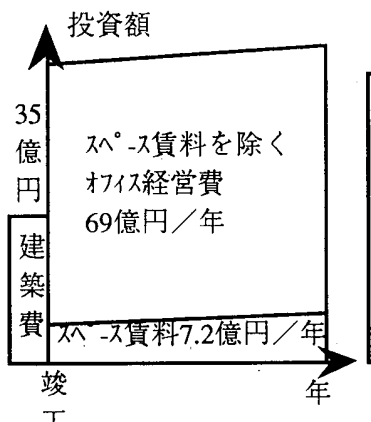

I
計算条件

\begin{tabular}{|c|c|}
\hline 建築延床面積 & $10,000 \mathrm{~m} 2$ \\
\hline 建築単価 & 115.5 万円 $/$ 坪 $(35$ 万円 $/ \mathrm{m} 2)$ \\
\hline 賃貸比率 & $75 \%$ \\
\hline 賃料 & 2.64 万円 $/$ 月坪 (8千円 $/$ 月 $\mathrm{m} 2)$ \\
\hline テナント従業員数 & 625 人（12m2／人） \\
\hline 才フイ経営費 & 11 百万円 / 人年 \\
\hline 勤務時間 & 7.5時間 $/$ 日 \\
\hline
\end{tabular}

\section{建築費}

35 万円 $/ \mathrm{m} 2 \times 10,000 \mathrm{~m} 2$ 玐 0 -傊料

8 千円 $/$ 月 $\mathrm{m} 2 \times 12$ 月 $/$ 年 $\times$ $10,000 \mathrm{~m} 2 \times 0.75=7.2$ 億円 $/$ 年

オフイス経営費

11 百万円／人年 $\times 625$ 人 $\quad \fallingdotseq 69$ 億円 $/$ 年

図 2 テナントモデルの投資額

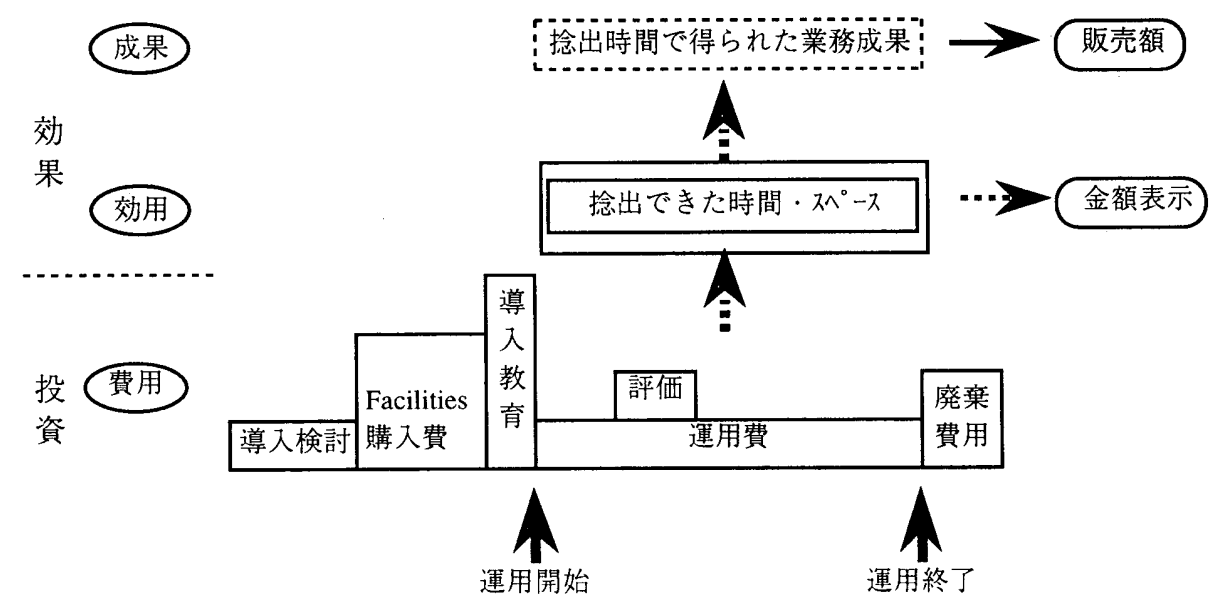

\section{投資効果の計算法}

投資額は、Facilitiesそのものの費用ば かりでなく、個別条件を反映させるた めの設計要求条件整理（導入検討）に 要した人件費の他、導入教育、運用並 びに廃棄に要する費用を合計する

効果の額は個別条件を反映させること により捻出できた時間の人件費換算と スペースの貨料換算とする

効果を商品の販売額で捉えていないた め、投資効果の判定は仮判定にとどま

図 3 テナントモデルの投資と効果 
4)。このモデルでは、1 年目で損益が平衡すれば 2 年目から利益 が出始め、Facilitiesの1次リース期間が終了すれば利益が増大す る。費用と効果並びに効果持続期間がシナリオ通りになれば、最終 的には利益を得ることが出来、その源泉がP D Rであるので、以下 では本モデルをプロフィットセンターモデルと呼ぶ。導入検討期間 を費用に換算する方法並びに捻出スペース及び捻出時間から効果を 金額に換算する式を表 1 に示す。

\section{$3-2$. 試算 1 : 有効スペースの捻出}

会議室の利用パターンを読み取り、会議室定員の組み合わを適正
化しスペースを削隇する場合が相当する。従来通りのスペース配分 や柱壁の位置から建て易い場所に壁を立て込む設計に比べると、運 用中の会議室の利用状況の記録 - 分析 - 予測 - 意思決定の費用が追 加となる。部屋数が同じでスペースが削減出来るなら会議室の

Facilities費用も運用費も増加しないと考えられる。

個別解を求める費用のみ追加となるので、捻出スペースとの関係 が単純になる（図 5-a）。導入検討に 1 人月要したなら費用は百 万円で、損益が平衡する有効スペースは約 $10 \mathrm{~m} 2$ となる。計算プロ セスを表 2 に示す。

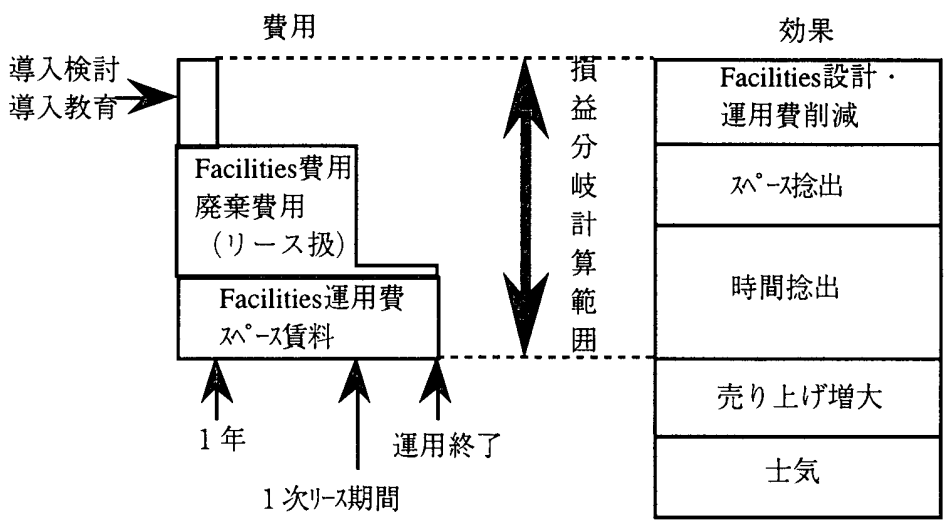

考え方

図 3 のFacilities費用をリース扱いと することにより、廃棄費用と公租公 課及び物価上界を無視できる。

導入検討費用と導入教育費用を初年 度で回収するモデルで、初年度の費 用と効果が平衡すれば、 2 年目から 利益が生まれ、1次りース期間終了 後は利益が増大する。

図 4 プロフィットセンターモデルによる損益分岐点計算の考え方

表 1 導入検討費用と効果の金額換算式

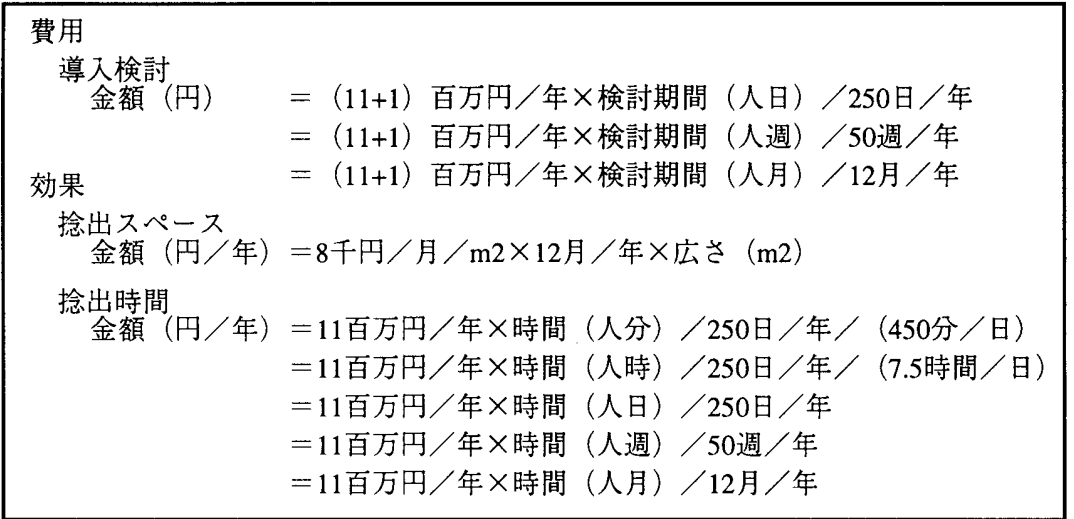

\section{考方方}

導入検討にはスペースも利用するので、 導入検討期間の換算には、オフィス経営 費（11百万円 $/$ 年）とスペース賃料 （1百万円／年）の合計を用いる。 なお、1 人当りのスペース賃料は 8 千円 $/$ 月 $\mathrm{m} 2 \times 12$ 月 $/$ 年 $\times 12 \mathrm{~m} 2$ $\doteqdot 1$ 百万円 $/$ 人年

効果の金額表示は、効果がスペース捻出 なら賃料に換算し、時間捻出ならオフィ ス経営費に換算する

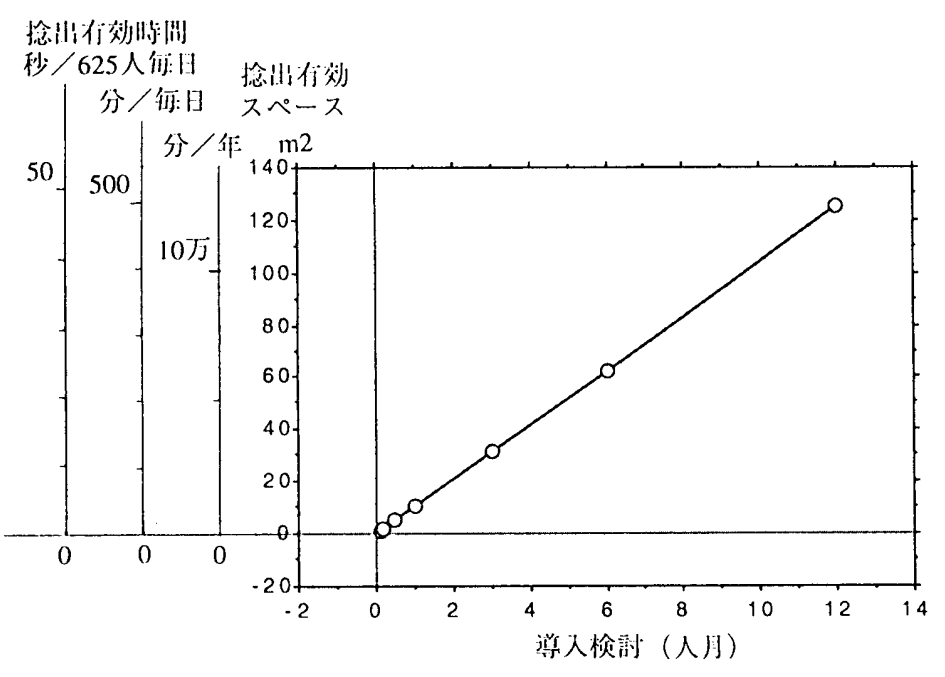

図 5-a 導入検討期間と捻出有効スペース/有効時間
表 2 有効スペース捻出事例の損益計算

費用：導入検討に 1 人月要したなら

$(11+1)$ 百万円 $/$ 年 $\times 1$ 人月 $/ 12$ 月 $/$ 年 $=1$ 百万円 目標効果

1 百万円 $=8$ 千円 $/$ 月 $\mathrm{m} 2 \times 12$ 月 $/$ 年 $\times \mathrm{Xm} 2$ より $\mathrm{X}=10.4 \mathrm{~m} 2$ 


\section{$3-3$ ．試算 2 : 有効時間の捻出}

近接必要性に基づきグループを配置し、グループ間の行き来の時 間を削減する場合が相当する。従来通りのグループの並びによる設 計に比べ、アシケートの作成・説明·配布 · 回答·回収 ·集計·分 析ならびに意思決定の費用が追加となる。Facilities費用や運用費の 増減は無いと考えられる。効果は移動時間が延長されるグループと 短縮されるグループとの增減時間の差引となる。

個別解を求める費用のみが追加となるので、捻出時間との関係が 単純で、図 5-aの第 2 Y軸との関係になる。表 1 と図 5-aよ り、個別解を捜すために、アンケートの作成・説明・配布 · 回答 . 回収·集計·分析ならびに意思決定に 1 人月要したなら、費用は百 万円で、損益分岐業務時間は10277人分であることが分かる。効果 が毎日発揮されるなら 1 日当り 41 人分、影響範囲が 41 人なら毎日 1 分、 625 人全員に影響するなら毎日約 4 秒の有効時間が捻出出来れ ば良い。計算プロセスを表 3 に示す。

3-4. 試算 $3:$ Facilitiesを追加し有効時間を捻出

席外しの多い組織で不在時のコミュニケーションの手間を削減し 意思決定をスピードアップするために導入するVoiceメールが相当す る。何もFacilitiesを追加しない場合と比較すると、Facilities仕様決定 のための要求条件整理やFacilities購入費および運用費並びに廃育費 用が追加となる。運用費にはスペース貨料が入る場合もある。効果

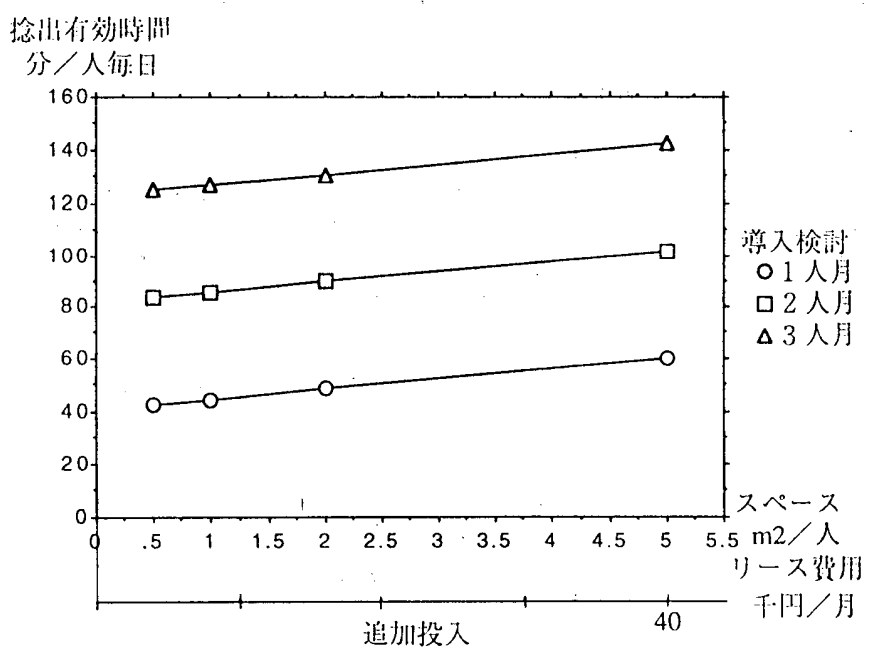

図 5-b 1 人当りの増加スペースと捻出有効時間

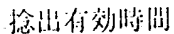

秒 $/ 625$ 人行: 日

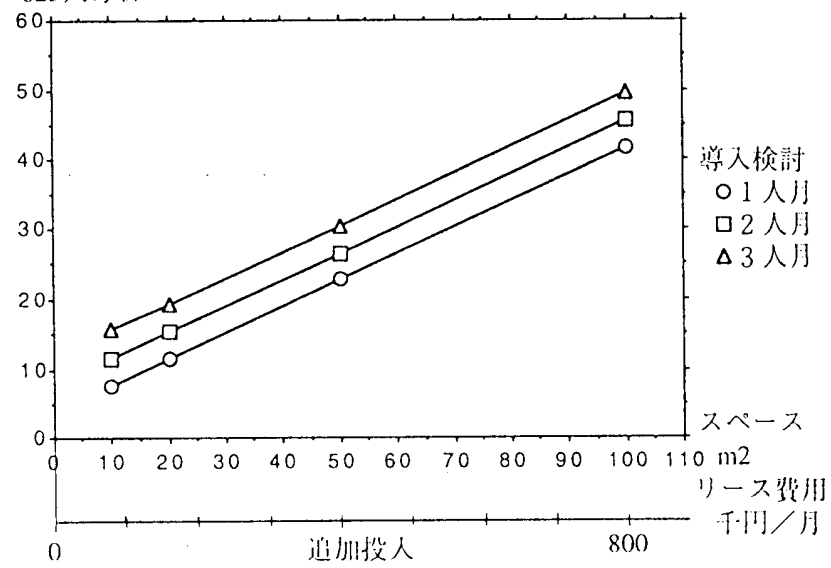

図 5- c 全体の増加スペースと捻出有効時間
は連絡が完結するまでに繰り返し呼びかける手間の削減や、返答が 返ってから次ぎの行動に移るまでに生じる手待ちの削減により捻出 できる時間となる。

投資側のパラメーターが複数あるため投資と効果の関係を単純に 捉えることが出来ない。そこで個別解を求めるための時間をいくつ か設定し、スペース又はFacilitiesのリース月額と有効時間の関係を 単純なグラフで示す（図 $5-b 、 c)$ 。図 5 -bは個人用スペー ス、図 $5-c$ は共用スペースを想定した表示とした。

ある個人の業務効率を高めるため、導入検討に 1 人日使い、ス ペースを 1 割・(1.2m2) 増加させ、購入価格30万円のFacilitiesを付加 したとすると、初年度の費用は導入検討費が48千円、運用費が193 千円／年で合計 $240 千 円 ／$ 年となる。捻出すべき有効時間は 2455 人 分で、効果が毎日継続するなら約10分となる。計算プロセスを表 4 に示す。

共用Facilitiesを充実させるのに、導入検討で 1 人月要し、Facilities の購入価格が 465 万円注10) 増、スペースが $30 \mathrm{~m} 2$ 増とすると、初年度

\section{表 3 有効時間捻出の損益計算事例}

費用：導入検討に1人月要したなら

$(11+1)$ 百万円 $/$ 年 $\times 1$ 人月 $/ 12$ 月 $/$ 年 $=1$ 百万円

目標捻出時間

1 百万円 $=11$ 百万円 $/$ 年 $\times X$ 人分 $/ 250$ 日 $/$ 年 $/ 450$ 分 $/$ 日上り $\mathrm{X}=10227$ 人分

効果が 1 人に毎日発揮されるなら 10277 人分 $/ 250$ 日 $/$ 年 $=41$ 人分 $/$ 日（ 1 年間）

効果が 41 人に毎日発揮されるなら 41 人分 $/$ 日 $/ 41$ 人 $=1$ 分 $/$ 日（ 1 年間 $)$ 効果が 625 人に毎日発揮されるなら 41 人分 $/ 625$ 人 $\times 60$ 秒 $/$ 分 $=3.9$ 秒 $/$ 人日

表 4 Facilities充実による有効時間捻出の損益計算事例（1 人用）

費用：導入検討に 1 人日要したなら

$(11+1)$ 百万円 $/$ 年 $\times 1$ 人日 $/ 250$ 日 $/$ 年 $=48$ 千円

Facilities購入費用 30 万円のリース年額 300 千月 $\times 0.258$ 洋 10$)=77.4$ 千月 $/$ 年

増加スペース $1.2 \mathrm{~m} 2$ の賃料年額 8 千円 $/$ 月 $\mathrm{m} 2 \times 12$ 月 $/$ 年 $\times 1.2 \mathrm{~m} 2=115.2$ 千円 $/$ 年

目標捻出時間

240 千円 $/$ 年 $=11$ 百万円 $/$ 年 $\times X$ 人分 $/ 250$ 日 $/$ 年 $/ 450$ 分 $/$ 日 より

$X=2455$ 人分 $($ 初年度)

効果が毎日発揮されるなら

2455 人分 $/ 250$ 日 $/$ 年 $=9.82$ 人分 $/$ 日（初年度）

表 5 Facilities充実による有効時間捻出の損益計算事例（共用）

費用：導入検討に 1 人月要したなら

$(11+1)$ 百万円 $/$ 年 $\times 1$ 人月 $/ 12$ 月 $/$ 年 $=1$ 百万円

Facilities費用 465 万円のリース年額 4.65 百万円 $\times 0.258$ 洋 $1=1.2$ 百万 $/$ 年

増加スペース $30 \mathrm{~m} 2$ の貢料年額 8 千円 $/$ 月 $\mathrm{m} 2 \times 12$ 月 $/$ 年 $\times 30 \mathrm{~m} 2=2.88$ 百万円 $/$ 年

目標捻出時間

5.1 百万円 $/$ 年 $=11$ 百万円 $/$ 年 $\times X$ 人分 $/ 250$ 日 $/$ 年 $/ 450$ 分 $/$ 日 より

$\mathrm{X}=52159$ 人分（初年度）

効果が毎日発揮されるなら

52159 人分 $/ 250$ 日 $/$ 年 $=208.6$ 人分 $/$ 日（初年度）

効果が625人に及ぶなら 52159 人分 $/ 250$ 日 $/$ 年 $/ 625$ 人 $=20.0$ 秒 $/$ 日人 
の費用は順に 1 百万円、 1.2 百万円、2.9百万円で合計5.1百万円とな る。捻出すべき有効時間は約52000人分で、効果が毎日継続するな ら約 210 人分 /日、影響範囲が 625 人なら毎日約 20 秒となる。計算プ ロセスを表 5 に示す。

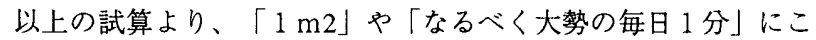
だわったP D Rは費用回収の可能性が高いことが分かる。また、 Facilitiesに追加費用が必要であっても、結果として捻出できるス ペースや時間の大きさ並びに効果の持続期間により、プロフィット センターとなりうることが明らかである。

\section{4. 結果と考察}

テナントの支出に注目し、Facilities追加はリースとし導入検討費 用は 1 年で回収するというプロフィットセンターモデルで費用対効

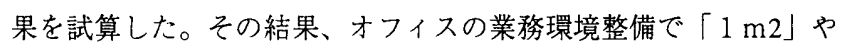
「なるべく大勢の毎日 1 分」に拘り個別事情の反映に努力する価値 のあることが明らかとなった。

プロフィットセンターモデルでは、効果の予測持続期間を基本 リース期間として求められる初年度損益分岐点をクリヤーできるな ら、計量できる効果だけでも 2 年目から利益を出し始める。従って 計量困難な部分も含めた効果が投資と平衡する「雑巾を絞った」設 計を目指すなら、本論文に示す目安以上の時間を導入検討に割くこ とが出来る。

逆に、個別事情を反映させずに設計した場合に活用できなくなる スペースや時間はテナント側の経営資源の浪費となり、年数を経る につれ、導入検討に要する費用より遥かに大きな額となりうる。

事務所ビルのP D R は、テナントの総支出に注目し経営資源の適 切な配分と活用を考慮することが必要で、要求条件整理に始まる導 入検討の果たす役割が重要であることが再確認できた。

尚、「雑巾を絞る」設計は前提条件が变化した場合の吸収しろが 無いことを意味するため、改造が容易でないFacilitiesに適用すると 問題が生じる可能性がある。リスクマネジメントも配慮した「雑巾 を絞る」設計の適用限界の検討も必要である。

注

1）参考文献 1、pp. 31

2) 参考文献 $2 、$ pp. 3

3) 参考文献 $2 、 3$

4) 参考文献 2、pp. 30

5) 参考文献 4、pp. 129

6）参考文献 2、pp. 11

7 ）建設省モデルは、運用費・建設費・修縉改良費・保全費 ·建設費 · 一般管理費・企画設計費

B E L C A モデルは、建設費・保全費・修糦費・更新費・運用費 · 一般管理費・企画設計費

いずれも参考文献 2、pp.3より

8）図2の集計結果が単純な数値となるよう以下の情報を参考に設定した

建築単価：参考文献 7、pp. 127に述べ休面積4493m2、SRC造、 地下 1 階、地上 9 階建ての賃貸事務所の建築費として1470古万円 の事例がある。 $\mathrm{m} 2$ 単仙に換算すると、327一円 $/ \mathrm{m} 2$ となる。

スペース賃料：参考文献 8、pp.7にベンチマークデーターの平均 として $96916 \mathrm{H} / \mathrm{m} 2$ 年の事例がある。 月単価に換算すると、8076四/月 $\mathrm{m} 2$ となる。

オフィス経営費：労務費十光熱通信費十賃貸料（除スペース）とする 労務費は参考文献 9 に電力ガス 16 社の平均値として 8577 千四／年（平成 1 年）加 10687 千仃/作 (平成 8 年) 光熱通信費は文献12の対学務費比率が平成 1 年から 8 年で $4.7 \%$ と.1\%の間で $5.8 \%$ 前後にバラつく
賃貸料は文献 12 で対労務費比率が平成 1 年の $13 \%$ から 8 年の $26 \%$ に潮增している。但し、文献12の賃借料ではスペース賃料並び に試験研究用の賃借料の区別が無い、

各年度におけるオフイス経営費を

労務費 $\times(1+$ 光熱通信費比率＋貨借費比率 $)$ とすると、 10.3 百万円 $/$ 年 (平成 1 年) 加 14.1 百万円 $/$ 年

労務費 $\times(1$ 光熱通信費比率十賃借費比率／2）とすると、 （賃貸料のうちスペース賃料と試駼研究用を半分と仮定） 9.7百万円 $/$ 年 (平成 1 年) から 12.7 百万円 / 年に增加する

従って、オフィス経営費の設定値11百万円は現実的と考えられる 1 人当りスペース：参考文献10、pp. $38 に 1 \mathrm{~m} 2$ 刻みの頻度分布が報告 されている。平均は $10.9 \mathrm{~m} 2 /$ 人で、 $12 \mathrm{~m} 2 /$ 人は狭いほうから数之 て70\%程度に位置する

9) 比率は以下のように求めた。

・ビル運用費は建設省モデルとBELCAモデルの建築哝垻とそれ以外の比率 を用いて逆算した

・オフィス経営費は物価上昇を無視し単純集計した

・テナントモデルのスペース賃料は建築費とビル運用費に含まれるため

除外した

ビル運用費

35 億円 $/ 15.9 \% \times 84.1 \%=185$ 億円 （65年モデル）

35 億円 $/ 25.3 \% \times 74.7 \%=103$ 億円 （40年モデル）

オフィス経営費

69億円 $/$ 年 $\times 65$ 年 $=4485$ 億円 $\quad(65$ 年モデル $)$

69 億円 $/$ 年 $\times 40$ 年 $=2760$ 億円 $\quad(40$ 年モデル $)$

建築費の比率は

\begin{tabular}{|c|c|c|}
\hline & 65年 & 40 年 \\
\hline 建築費 & 35億円（ $0.7 \%)$ & 35 億円 $(1.2 \%)$ \\
\hline ビル運用費 & 185億円( $3.9 \%)$ & 103億円( $3.6 \%)$ \\
\hline オフィス経営費 & 4485億円(95.4\%) & 2760億円( $95.2 \%)$ \\
\hline
\end{tabular}

10）Facilitiesの購入俩格とリース年額の関係は参考文献 $11 、 p p .40$ の表I-2に、 物件価格10百万円に対しリース年額2.58百万円の関係が示されている。 リース条件は、

物件価格 10 百万円

リース期間 5 年（法定酎用年数 8 年、定率法の償却率 0.25 )

リース料棇額 12.9 百万円

調達コスト $7 \%$

税金 $55 \%$ （法人税、事業税等）

固定資産税 $14 / 1000$ (期初の物件の簿価に対して、年)

保険料 $\quad 3 / 1000$ (期初の物件の簿佂に対して、年)

販管費・利益 $1 \%$ （物件価格に対して、年）

参考文献

1）木村利雄、エレベータ・エスカレータ・立体駐車場、学芸出版社、1979.7

2 ）建設省住宅局建築物防災対策室監修、（社）建築 ·設備維持保全推進協 会編著、ビルデイングL C ビジネス百科、オーム社、1996.6

3 ）建設大臣官房官庁営鐥部監修、（財）建築保全センター編集、建築物の ライフサイクルコスト、（財）経済調査会、1993.10

4) 井上字市、高田秋一、コジェネレーション技術入門、オーム社、1992.6

5 ) M.Brill, et al、Using Office Design to Increase Productivity、Workplace Design and Productivity, Inc. 1984

6）加藤力編著、オフィスインテリアのプランニング\&デザイン、K B I 出 版、1992

7) 不詳、建築費決定のメカニズム、日経アーキテクチャー、1993.9.13

8) 小田昆古、ベンチマーク調査研究部会、JFMA newsletter、日本ファシリ ティマネジメント推進協会、1997.9

9）通産省産業政策局編、わが国企業の経営分析一業種別統計鍽、大蔵省印 刷局、年刊

10）ニューオフイス推進協議会、平成 9 年度生活文化産業対策調查報告書一 オフィス寒態調查、ニューオフィス推進協議会、1998. 3

11）森住祐治、リース取引の実際、日経文庫、1986.2

12）大阪ガス、有㑣証券報告書、大阪ガス、年刊 